\title{
Chemical Modeling of Backfill Composed of Quartz Sand, Lime and an Fe-Phase
}

\author{
Annemarie Meike \\ William E. Glassley
}

This is an informal report intended primarily for internal or limited external distribution. The opinions and conclusions stated are those of the author and may or may not be those of the Laboratory.

Work performed under the auspices of the U.S. Department of Energy by the Lawrence Livermore National Laboratory under Contract W-7405-Eng-48. 


\section{DISCLAIMER}

This document was prepared as an account of work sponsored by an agency of the United States Government. Neither the United States Government nor the University of California nor any of their employees, makes any warranty, express or implied, or assumes any legal liability or responsibility for the accuracy, completeness, or usefulness of any information, apparatus, product, or process disclosed, or represents that its use would not infringe privately owned rights. Reference herein to any specific commercial product, process, or service by trade name, trademark, manufacturer, or otherwise, does not necessarily constitute or imply its endorsement, recommendation, or favoring by the United States Government or the University of California. The views and opinions of authors expressed herein do not necessarily state or reflect those of the United States Government or the University of California, and shall not be used for advertising or product endorsement purposes.

This report has been reproduced directly from the best available copy.

Available to DOE and DOE contractors from the Office of Scientific and Technical Information

P.O. Box 62, Oak Ridge, TN 37831

Prices available from (615) 576-8401, FTS 626-8401

Available to the public from the

National Technical Information Service

U.S. Department of Commerce

5285 Port Royal Rd.,

Springfield, VA 22161 


\section{Chemical Modeling of \\ Backfill Composed of Quartz Sand, Lime and an Fe-Phase}

Annemarie Meike and William E. Glassley

Environmental Programs Directorate

Lawrence Livermore National Laboratory

UCRL-ID-124631 


\section{Introduction}

From both mechanical and chemical perspectives, the area adjacent to the waste package is an important component of the engineered barrier system in a high level radioactive waste repository. Whereas the absence of backfill has economical and thermal advantages, a backfill may also perform positive functions such as providing a capillary barrier, reducing relative humidity, providing a drip shield, providing a diffusion, chemical or mechanical barrier, or providing external criticality control. Our objective has been to develop a materials-specific understanding of the chemical aspects of backfill options. The work is used to provide information on bounding conditions, uncertainties and sensitivity to various conditions in the repository. It is also used to estimate the chemical effectiveness of a particular backfill option. The information supports the selection of waste package materials and the selection of backfill options for performance assessment activities.

The primary focus of the present work has been to provide information on the effectiveness of specific backfill formulations for chemical conditioning of the waste package environment. Our purpose has been to determine whether the material options will provide the desired design effect and for how long, without considering whether this effect is desirable. The option under consideration in this study, a combination of lime, quartz sand and a phase that contains iron in a chemically reduced state, is investigated to determine whether it can achieve an intended twofold effect: first, the reduction of oxygen in the waste emplacement drift, thereby reducing corrosion rates and second, the increase of $\mathrm{pH}$ which would provide a beneficial environment for certain waste package materials (e.g. mild steels) at some later time. The effects of microbial activity and waste form composition must also be accounted for in the evaluation of these conditioning options. The material options presently under consideration are combinations of metallic iron (to reduce Eh ), lime (to increase $\mathrm{pH}$ ) and quartz sand (to give greater flexibility to the amounts of the other materials used). The present modeling effort is intended to provide insight into the long-term evolution of the backfill through a given thermal and relative humidity history which are based on hydrological modeling.

The simulations that have been conducted to date have examined the following backfill options: iron metal only, iron metal and lime, and iron metal, lime and quartz sand in equal volume ratios. Each of the backfill options was simulated under two environments: that for which air exchange with the atmosphere is limited and that for which air exchange is unlimited. The geometry of the backfill is such that it completely covers the canister but does not completely fill the drift. This set of chemical simulations is not to be taken as "realistic" or "conservative", but rather as a tool for determining whether a specific design strategy is worth pursuing further. Note that these simulations do not consider the impacts of microbial activity. Although the chemical models used in these simulations (EQ3/6, OS3D/GIMRT) apply to saturated systems, the results can also be applied to scenarios in which liquid water is present but not saturating the environment (unsaturated conditions). The present work could therefore be used to interpret chemical processes within a water film, or situations in which saturated steam is present. The simulations conducted using these modeling codes are limited by the absence of high quality data for a number of amorphous and crystalline phase in the $\mathrm{CaO}-\mathrm{SiO}_{2}-\mathrm{H}_{2} \mathrm{O}$ system that may be involved in the chemical processes under consideration. These phases occur in chemical sytems for which the bulk concentration of $\mathrm{Ca}$ is high with respect to $\mathrm{Si}$. The thermodynamic stability of many of these phases is sensitive to $\mathrm{CO}_{2}$ partial pressure, and a range of calcium carbonate and hydrous calcium silicate phases as well as silica polymorphs may form. Our ability to model chemistry in the absence of data for these phases is limited, which may affect the simulation of scenarios for high lime content backfill.

The results of the simulations suggest that the most important variable during the process of of chemical conditioning is the amount of air exchange that occurs in the emplacement drift. The desired chemical conditioning (both oxidation potential and $\mathrm{pH}$ ) will be far less effective in an emplacement that experiences an unlimited exchange of air with the atmosphere. 


\section{Background.}

\subsection{Backfill functions and their assessment.}

The potential engineering effects of backfill materials may include the control of radionuclide ( $\mathrm{RN}$ ) release, and the enhancement of containment. Controlled radionuclide release may be achieved by a number of different processes. These include: (1) RN sorption and retardation by solid phases such as zeolites (ion exchanger + ion sorber), (2) chemical conditions that retard the dissolution and thus the release of certain RN species (e.g. Np: Conditioned backfill that creates chemically reducing conditions), (3) precipitation of solid phases: either the reaction of certain RN (e.g. $\mathrm{Ca}^{14}$ ) to form precipitates (e.g. $\mathrm{Ca}^{14} \mathrm{CO}_{3}$ ), or the formation of a barrier to water flow or $\mathrm{RN}$ transport by advective flow through the precipitation of non-RN-bearing phases, and (4) low saturation and connectivity conditions that control diffusive transport. All of these potential scenarios need to be simulated over a range of temperatures since some processes may be more effective, and others less effective at elevated temperatures.

It is important to note that backfill is not a cure-all, and that backfill may have beneficial and non-beneficial effects on performance. For example, the presence of backfill raises WP container surface temperatures (Buscheck, 1996). The beneficial effects of keeping the drift warm and dry would be to reduce or eliminate microbial activity (see e.g. Horn and Meike, 1995), to slow corrosion (Vinson et al., 1995) and to delay the intrusion of water (Buscheck, 1996). As a consequence, degradation can be minimized provided temperature does not exceed a threshold value. In addition, given these considerations and that adequate thermodynamic databases are available for chemical modeling, it is possible that the degree of uncertainty can be decreased by increasing temperature. It is also possible that the appropriate choice of conditioned backfill may promote container lifetime by buffering $\mathrm{pH}$ to the desired value or retarding the exposure of uncorroded surfaces. However, some aspects of the presence of a backfill may not be beneficial. For example, backfill may produce microenvironments in which crevicing or pitting can occur, a substrate for the migration and re-entry of microbes once conditions are favorable, or a medium for capillary or wicking effects, all of which can ultimately accelerate corrosion.

Presently studies are being conducted to determine whether a backfill should be incorporated into a repository design strategy that could be applied to Yucca Mountain. In such an assessment it is imperative to demonstrate that the backfill material and packing design significantly outperforms a design in which no backfill is used. A complete assessment of the backfill and its ability to perform a desired engineering function should include an assessment of coupled effects. Table 1 provides a partial qualitative assessment of some candidate backfill materials with respect to these possible backfill functions. Table 2 provides a preliminary guide to coupled effects as an example of the potential competing processes that may produce undesired secondary effects. More complex coupled effects are material specific, and require chemical modeling to correctly characterize. This study considers some of those chemical characteristics which may influence the performance of waste container materials.

The purpose of applying sophisticated modeling capabilities to backfill, invert and packing material design is to determine whether the desired engineered functions are satisfied. For example, it is critical that we demonstrate that the timing of a chemical conditioning effect coincides with the need for that effect (e.g. chemical effects that control radionuclide release must be in effect after containers are breached). The models are also used to define bounding conditions and degrees of uncertainty and as a result, to better constrain sensitivity studies. Modeling can assist in the identification of issues critical to the effectiveness of the materials to perform a desired function. As a consequence, experiments critical to license application can be identified. This type of evaluation is essential, not only for candidate backfill materials but also for packing and invert materials, multi-barrier concepts, and entire emplacement drift concepts. 
Table 1: Qualitative Evaluation of Engineering Functions for Selected Backfill Materials.

\begin{tabular}{|c|c|c|c|c|c|c|c|c|c|c|c|c|c|c|}
\hline Function & Criticality & $\begin{array}{l}\mathrm{pH} \\
\text { buffer }\end{array}$ & $\begin{array}{l}\mathrm{pH} \\
\text { effect on } \\
\text { WP }\end{array}$ & $\begin{array}{l}\text { Microbe } \\
\text { activity }\end{array}$ & $\begin{array}{l}{ }^{14} \mathrm{C} \\
\text { sink }\end{array}$ & $\begin{array}{l}\text { Redox } \\
\text { buffer }\end{array}$ & $\begin{array}{l}\text { Sorb } \\
\text { Water }\end{array}$ & $\begin{array}{l}\text { Sorb } \\
\text { Sequester } \\
\text { Radio- } \\
\text { nuclides }\end{array}$ & $\begin{array}{l}\text { Thermal } \\
\text { stability }\end{array}$ & $\begin{array}{l}\text { Reduce } \\
\text { permea- } \\
\text { bility }\end{array}$ & $\begin{array}{l}\text { Mechanical } \\
\text { strength }\end{array}$ & $\begin{array}{l}\text { Thermal } \\
\text { conduc- } \\
\text { tivity }\end{array}$ & $\begin{array}{l}\text { Material } \\
\text { already } \\
\text { present }\end{array}$ & $\begin{array}{l}\text { Colloid } \\
\text { filter }\end{array}$ \\
\hline No backfill & $t+$ & & & + & & & & & + & & & & + & - \\
\hline $\begin{array}{l}\text { Drip shied } \\
\text { only }\end{array}$ & ++ & & & & & & & & & + & & & -- & \\
\hline crushed tuff & $?$ & - & - & & & & & + (cations) & & & & & + & $t$ \\
\hline $\begin{array}{l}\text { crushed tuff + } \\
\text { vitrophyre }\end{array}$ & $?$ & - & - & & & & & ++ (cations) & & & & & + & $t$ \\
\hline $\begin{array}{l}\text { clay } \\
\text { (bentonite?) }\end{array}$ & & $?$ & & & & & $\begin{array}{l}+ \\
\mathrm{T}--\end{array}$ & $\stackrel{+}{\mathbf{T}--}$ & -- & $\begin{array}{c}+ \\
T--\end{array}$ & - & & + & \\
\hline concrete & $?$ & $?$ & $?$ & $?$ & $t$ & & + & + (cations) & - & & $\begin{array}{c}+ \\
T--\end{array}$ & & $?$ & $\cdots$ \\
\hline sulfides & & + & -- & -- & & & & + (anions) & & & & & -- & \\
\hline $\begin{array}{l}\text { charcoal/ } \\
\text { graphite }\end{array}$ & -- & & & - & -- & + & & + (anions) & & & & + & -- & - \\
\hline $\begin{array}{l}\text { metal/metal } \\
\text { oxide }\end{array}$ & -- & + & + & & & + & & + & & & & + & $t$ & -- \\
\hline
\end{tabular}

? little is known; + and ++ desired effect appears acheivable; - and -- desired effect will not be acheived; T effect at elevated temperature 
Table 2: Qualitative Evaluation of Coupled Effects

\begin{tabular}{|c|c|c|c|c|c|c|c|c|c|c|c|c|c|}
\hline Function & Criticality & $\begin{array}{l}\mathrm{pH} \\
\text { buffer }\end{array}$ & $\begin{array}{l}\text { pH } \\
\text { effect } \\
\text { on WP }\end{array}$ & $\begin{array}{l}\text { Microbe } \\
\text { Activity }\end{array}$ & $\begin{array}{l}{ }^{14} \mathrm{C} \\
\operatorname{sink}\end{array}$ & $\begin{array}{l}\text { Redox } \\
\text { buffer }\end{array}$ & $\begin{array}{l}\text { Water } \\
\text { sorption }\end{array}$ & $\begin{array}{l}\text { Radionuclide } \\
\text { sorption/ } \\
\text { sequestering }\end{array}$ & $\begin{array}{l}\text { Thermal } \\
\text { stability }\end{array}$ & $\begin{array}{l}\text { Reduce } \\
\text { permea- } \\
\text { bility }\end{array}$ & $\begin{array}{l}\text { Mechanical } \\
\text { strength }\end{array}$ & $\begin{array}{l}\text { Thermal } \\
\text { conduc- } \\
\text { tivity }\end{array}$ & $\begin{array}{l}\text { Colloid } \\
\text { filter }\end{array}$ \\
\hline $\begin{array}{l}\text { radionuclide } \\
\text { sorption/ } \\
\text { sequestering }\end{array}$ & $\bullet$ & & & $\bullet$ & & - & & & & & & & - \\
\hline criticality & & & & & & & & & & & & & \\
\hline pH & & & & $\bullet$ & & $\bullet$ & & - & & $\bullet$ & $\bullet$ & & $\bullet$ \\
\hline $\begin{array}{l}\text { microbial } \\
\text { influences }\end{array}$ & $\bullet$ & - & $\bullet$ & & & $\bullet$ & & $\bullet$ & & $\bullet$ & - & & - \\
\hline redox state & & & & - & & & & & & & & & $\bullet$ \\
\hline $\begin{array}{l}\text { relative } \\
\text { humidity }\end{array}$ & & & & $\bullet$ & & & $\bullet$ & & & & & & $\bullet$ \\
\hline temperature & & $\bullet$ & $\bullet$ & $\bullet$ & & & $\bullet$ & & & & & & - \\
\hline permeability & & & & & & & & & & & & & $\bullet$ \\
\hline $\begin{array}{l}\text { fracture } \\
\text { growth }\end{array}$ & & & & & & & & - & & - & - & & $\bullet$ \\
\hline $\begin{array}{l}\text { colloid } \\
\text { production }\end{array}$ & & & & & & & & $\bullet$ & & & & & . \\
\hline
\end{tabular}




\subsection{Modeling Packages}

\subsubsection{EQ3/6}

The EQ3/6 geochemical modeling package (Wolery et al., 1990) uses first principles and a database of fundamental thermodynamic parameters and user supplied reaction rate parameters to simulate the chemical evolution of a system. The output of the simulations are $\mathrm{pH}, \mathrm{Eh}$, mineral assemblages, and water chemistry (chemical speciation) as a function of time (reaction progress). These simulations provide important information to establish:

- whether the desired conditioning is achieved during approach to steady state (transient), or equilibrium conditions.

- the mechanisms responsible for contrasts in chemical properties of different systems (e.g. why $\mathrm{pH}$ differences are observed between "fixed" and " unfixed" gas phase $\left(\mathrm{fCO}_{2}\right.$ and $\left.\mathrm{fO}_{2}\right)$ cases), and

- steady state conditions between the water chemistry and solid phase assemblage, which represents an "endpoint" for the evolution of the system.

Physically, the exposure of the waste packages to oxygen and other atmospheric gases is limited by two possibilities. Either the drifts are ventilated by an engineered ventilation system or naturally through rock fractures, or the drifts are unventilated. The implication of this distinction is profound because it means the distinction between a system in which the gas composition and fugacities remain constant over time, and a system in which the gas composition evolves. These physical possibilities are simulated by setting two modeling options. First, the system parameters are set using the terminology "open", "closed", "titration" or "flow through", which determine the means by which reactants and precipitated phases enter and leave the system, and the duration for which the phases can react with the aqueous phases. All simulations in the present study were conducted in "titration" mode, implying that aliquots of reactants are added to $1 \mathrm{~kg}$ of water and allowed to react and that precipitated minerals reman in the system and continue to be potential reactants with the aqueous phase. Second, the gas fugacity parameters are set as either "fixed", which means the fugacity remains constant throughout the simulation (equivalent to a ventilated system) or "unfixed", which allows the fugacities to evolve over time. In these simulations the fugacities for the fixed case were set at atmospheric values.

The results of the EQ3/6 simulations are used to select the significant chemical properties of the system. These properties are then used in the OS3D/GIMRT reactive transport code, which has reduced the maximum number of chemical species that can be involved in a simulation in order to streamline the simulations.

\subsubsection{OS3D/GIMRT}

The OS3D/GIMRT reactive transport package is a first principles reactive transport code (Steefel and Lasaga, 1994; Steefel and Yabusaki, 1995) that simulates chemical changes in an aqueous fluid as it moves through a porous medium. It also determines the evolution of mineralogy and porosity as the aqueous fluid reacts with the porous medium, thus providing a model of the time dependent evolution of the physical framework of the flow field. As mentioned above, the simulations rely on first principles chemical modeling (e.g. EQ3/6) for the selection of appropriate input parameters. The output of the simulations shows spatial and temporal chemical and mineralogical changes due to the reactive transport of water through a saturated permeable material. Spatial simulation shows reaction fronts and time sequence evolution as a function of flow rate, thermal gradient, and water chemistry. Although the precipitation of solids is simulated, the formation of an impermeable layer, or crust, is not part of the simulation. Nevertheless, the formation of a crust may have a great impact on hydrology and depends on grain size, ratio of the 
components and reaction rates. The formation and impact of such a crust will be evaluated at a later date.

In general it is possible to recognize three distinct regions of chemical evolution that are illustrated by the cartoon representation in Figure 1. The three regions are: the initial condition (represented in light gray), the input condition, represented in dark gray, and the transition zone , which with time, moves through the system, represented in black. It is important to note that the transition zone itself evolves toward a stable (mature) chemical profile over time. The length of the transition zone and the speed at which it travels through the system depend on infiltration rate and water chemistries. This simple visualization demonstrates that understanding the chemical process responsible for the conditioning effect is fundamental to determining its timing and its potential duration. Clearly, if the chemical effect occurs within the transition zone, then the engineering objective would be to make the transition zone as wide as possible and move it as quickly as possible to contact the waste package (at $1.0 \mathrm{~m}$ ). If the chemical conditioning effect occurs within the initial state, then the object would be to slow the rate of the transition zone movement to the extent possible.

\section{Simulation Strategy}

A complete analysis of the chemical conditioning effects of candidate backfill materials involves a series of simulations that test a number of composition parameters over a range of temperatures, grain sizes, and water chemistries. We recommended a simulation strategy in which the overall chemical characteristics of selected systems would be defined using EQ3/6, which would establish the detailed chemical behavior of the system in the absence of fluid flow. The chemical characteristics that should be most thoroughly considered would be the ability of the Fe-phase to maintain low oxygen partial pressures, the ability of the $\mathrm{CaO}$-phase to buffer the $\mathrm{pH}$ at high values, the sensitivity of the backfill system to the degree of drift ventilation, and the impact of interactions between the backfill components on the overall buffering capacity.

Information developed through these simulations would then be used to select the significant chemical species to be considered in simulations that account for the effects of fluid flow, and the simulations would be carried out using the OS3D/GIMRT reactive transport code package. The results of these simulations would define the spatial distribution of reaction fronts, fluid chemistries, and steady state conditions as a function of time. A thorough analysis of reactive transport would include simulations of at least two flow rates and two thermal gradients for one selected water chemistry, and one flow rate and one thermal gradient for the other two waters. Sensitivity studies are required for physical variables such as particle size and porosity, as well as variation in the relative proportion of backfill components. Ultimately, this information would establish the extent to which the conditioning goals would be met for a given backfill emplacement scenario.

We recommended that three different fluid chemistries be considered. One fluid was J-13, which is a naturally occurring dilute, bicarbonate water that has chemical characteristics which approximate those of waters in contact with tuffs similar to those of the proposed repository horizon. A second fluid was one which approximated the chemical characteristics expected of water that equilibrates with concrete. This was selected based on the possibility that concrete may be a common material used within emplacement drifts. A third water was a brine equilibrated with concrete. This solution was considered based on the possibility that salts and carbonates of various chemical elements are expected to be deposited in the vicinity of emplacement drifts, as a result of evaporation and boiling of pore waters during the heating phase of the repository. Because of funding limitations, only a subset of the recommended simulations were completed (see Table 3). 
Table 3: Simulation conditions (recommend EQ3/6 (X), recommend OS3D/GIMRT $(\mathbf{O})$, and funded $(\bullet))$ and solid phases considered in the reacting systems.

\begin{tabular}{|c|c|c|c|c|}
\hline $\begin{array}{l}\text { Chemical System } \\
\text { and Water Type }\end{array}$ & $\begin{array}{l}\mathrm{O}_{2} \text { and } \mathrm{CO}_{2} \\
\text { Uncontrolled }\end{array}$ & $\begin{array}{l}\mathrm{O}_{2} \text { Fixed At } \\
\text { Atmospheric } \\
\text { Value, } \mathrm{CO}_{2} \\
\text { Uncontrolled }\end{array}$ & $\begin{array}{l}\mathrm{O}_{2} \text { and } \mathrm{CO}_{2} \\
\text { Fixed at } \\
\text { Atmospheric } \\
\text { Values }\end{array}$ & $\begin{array}{l}\mathrm{O}_{2} \text { Fixed at } \\
\text { Atmospheric } \\
\text { Value, } \mathrm{CO}_{2} \text { Fixed } \\
\text { at High Value }\end{array}$ \\
\hline \multicolumn{5}{|l|}{$\mathrm{Fe}^{\circ}$ or Magnetite } \\
\hline Concrete Water & $x$ & $x$ & $\begin{array}{l}\mathbf{X} \\
\mathbf{X}\end{array}$ & $\begin{array}{l}X \\
X\end{array}$ \\
\hline \multicolumn{5}{|l|}{$\begin{array}{l}\mathrm{Fe}^{\circ} \text { or Magnetite + } \\
\mathrm{CaO}\end{array}$} \\
\hline J-13 Water & $x \bullet$ & $x \bullet$ & $x \bullet$ & $\mathbf{x}$ \\
\hline Concrete Water & $x$ & $\mathbf{x}$ & $x$ & $\mathbf{X}$ \\
\hline \multicolumn{5}{|l|}{$\begin{array}{c}\mathrm{Fe}^{\circ} \text { or Magnetite + } \\
\mathrm{CaO}+\mathrm{SiO}_{2}\end{array}$} \\
\hline J-13 Water & xo • & Xo. & xo. & xo \\
\hline Concrete Water & xo & xo & xo & Xo \\
\hline $\begin{array}{l}\text { Concrete+Brine } \\
\text { Water }\end{array}$ & xo & XO & $\times 0$ & Xo \\
\hline
\end{tabular}

The completion of the assessment includes a statement of important factors affecting uncertainty, which include the impact of microbial activity and such reactions that involve chemical species present in the backfill as impurities or that may be present in other parts of the system (e.g. $\mathrm{Ca}_{(\text {aq) }}+\mathrm{SO}_{4}{ }_{(\text {(aq) }}+\mathrm{H}_{2} \mathrm{O} \Leftrightarrow=>$ gypsum).

In addition to this exercise conducted with a specific backfill material, the GEMBOCHS thermodynamic database was reviewed in order to discover other backfill materials with the potential for producing elevated $\mathrm{pH}$ or depressed Eh effects over long periods of time.

\subsection{Completed EQ3/6 Simulations}

The EQ3/6 simulations were conducted in three parts (Table 3). The first part was designed to test aspects of $\mathrm{fO}_{2}$ conditioning. The simulated system consisted of a solid Fe species ( $\mathrm{Fe}^{0}$ or magnetite) and $\mathrm{J} 13$ water. Each case was simulated for both fixed and unfixed $\mathrm{fO}_{2}$ cases and at a constant temperature $\left(90^{\circ} \mathrm{C}\right)$. No significant difference was observed between simulations using magnetite and those that used $\mathrm{Fe}^{0}$ even though their reaction rates are not equal. Table 4 shows the phases and hydrolysis reactions considered in these simulations. Barring those redox scenarios that cannot be simulated because of the absence of applicable thermodynamic data we conclude that the results using magnetite are representative of both elemental iron and magnetite bearing backfill, and omitted the $\mathrm{Fe}^{0}$ case in the remaining simulations. In addition, whereas both greenalite and hematite were simulated reaction products of the iron phases ( $\mathrm{Fe}^{0}$ or magnetite) using $\mathrm{EQ} 3 / 6$, the OS3D/GIMRT simulations were simplified such that all the iron phase reaction products occured as hematite (which has a reaction rate that is faster than greenalite). This approach is conservative in the sense that reaction rates are higher for the modeled system, thus allowing steady state to be achieved faster. If the final chemical conditioning affect is not achieved in the scenario it will certanly not be achieved in the magnetite scenario.

The second part consisted of a sensitivity study of the system with respect to $\mathrm{CO}_{2}$. The simulated system consisted of solid $\mathrm{Fe}^{0}$ and $\mathrm{CaO}$, in a molar ratio of $1: 1$, and $\mathrm{J} 13$ water. In this case a simulation in which both $\mathrm{fCO}_{2}$ and $\mathrm{fO}_{2}$ were fixed was compared to a simulation in which both were 
unfixed. In all cases, when gas fugacities were fixed, $\mathrm{fCO}_{2}$ was fixed at a value of $3.16 \mathrm{e}-4$ bars, and $\mathrm{fO}_{2}$ was fixed at a value of 0.2 bars.

In the third part of the EQ3/6 simulation exercises, the complete matrix of $\mathrm{fO}_{2}$ and $\mathrm{fCO}_{2}$ values, and $\mathrm{J} 13$ water was tested for a molar ratio of $80: 15: 5$ quartz sand, $\mathrm{Fe}^{\mathrm{O}^{*}}$, and lime, respectively.

Optimally the simulations should be conducted over a range of porosities, grain sizes, packing geometries, temperatures and temperature gradients. However, due to time and budget constraints the following subset of conditions used in the simulations were agreed upon by the authors and members of the Yucca Mountain Performance Assessment System Study group:

1) all backfill materials are $7 / 16$ in. diameter,

2) $40 \%$ porosity,

3) calculated cross section for backfill model $=3.1138 \mathrm{~m}^{2}$ (using angle of repose geometry, and subtracting invert and WP), and

4) A backfill volume $=7.78 \times 10^{5} \mathrm{~m}^{3}$ was calculated using our cross section and an estimated length, $\mathrm{L}=2.5 \times 10^{5} \mathrm{~m}$ (Sassani, 1995), for estimating surface area.

Table 4. Data for solid Fe metals, oxides and hydroxides contained in the thermodynamic database.

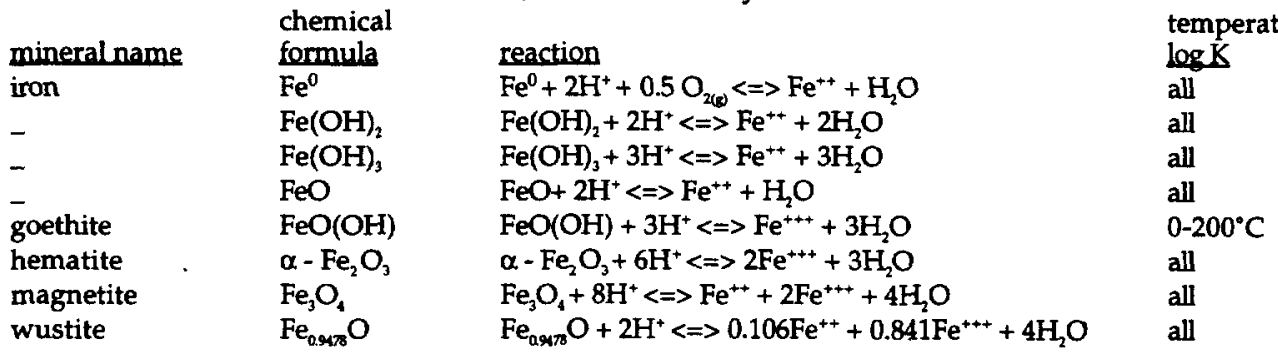

\subsection{Completed OS3D/GIMRT Simulations}

One-dimensional OS3D/GIMRT simulations were run for a path length of $1.0 \mathrm{~m}$, an infiltration rate of $10 \mathrm{~mm} /$ year, temperature of $90^{\circ} \mathrm{C}$, and an initial porosity of $40 \%$. It was assumed that the system was initially saturated with a low ionic strength aqueous solution, which was progressively displaced by J-13 water as flow occurred. This approach was chosen in order to simulate reaction of the backfill with a high relative humidity $(100 \%)$ atmosphere, prior to infiltration of the J-13 water.

Infiltration of J-13 into the backfill results in the formation of a reaction front between the intial pore water and the infiltrating water. This reaction zone is mobile and moves through the system and ultimately disappears at the outlet $(1.0 \mathrm{~m})$, leaving behind the altered backfill material (Figure 1), which represents a steady state condition. Note that a dryout condition is not simulated. Clearly, a waste package located at the outlet will experience different chemistries through time. Simulations showing the location and chemistry of reaction fronts as a function of time have been conducted for a single flow rate and a constant temperature $\left(90^{\circ} \mathrm{C}\right)$. No temperature gradient simulations have yet been conducted. All simulations are for the $\mathrm{SiO}_{2}: \mathrm{CaO}: \mathrm{FeO}$ molar ratio 80:15:5 and J13 water. The reaction rates are based on values obtained from the literature as described in Table 5 below.

\section{Results}

The results of EQ 3/6 simulations of magnetite, lime, quartz sand system (80:15:5 molar ratio), are shown in Figure 2. Both $\mathrm{pH}$ and Eh are illustrated as a function of reaction progress for both a closed (unventilated) system (no gas control, i.e. "unfixed" $\mathrm{fO}_{2}$ ) and an open(ventilated) system (gas control, i.e. "fixed" $\mathrm{fO}_{2}$ ). From these results it is clear that the equilibrium $\mathrm{pH}$ of a system that allows free exchange with the atmosphere (open system, Figs $2 \mathrm{c}$ and $\mathrm{d}$ ), and reaction in the presence 
equilibrium $\mathrm{pH}$ of around 10.25 only until the lime is reacted. Subsequently the $\mathrm{pH}$ decreases, first to a $\mathrm{pH}$ of around 9.5. The second $\mathrm{pH}$ drop to rouphly 9 corrolates with the consumption of the iron phase.

Table 5. Reaction rates used in OS3D/GIMRT calculations.

\begin{tabular}{|c|c|c|}
\hline Phase & Rate $\left(\right.$ moles $\left./ m^{2} / \mathrm{sec}\right)$ & Source \\
\hline lime & $1 \times 10^{-8}$ & Estimate (real value is probably faster). \\
\hline quartz & $3.3 \times 10^{-10}$ & $\begin{array}{l}\text { Data from van Lier et al. (1960) at } 90^{\circ} \mathrm{C} \text { are consistent } \\
\text { with Knauss and Wolery }(1988) \text { at } 70^{\circ} \mathrm{C} \text { and near neutral } \mathrm{pH} \text {. }\end{array}$ \\
\hline magnetite & $4.0 \times 10^{-13}$ & $\begin{array}{l}\text { Extrapolated from data from White et al.(1994) } \mathrm{pH} 5.0 \text {, } \\
\text { who measure values in the range of } 2-65.0^{\circ} \mathrm{C} \text {. }\end{array}$ \\
\hline hematite & $9.93 \times 10^{-11}$ & $\begin{array}{l}\text { Calculated from Bruno et al. (1992) for a system at } 25^{\circ} \mathrm{C} \\
\text { containing elevated concentrations of carbonate. Calculated } \\
\text { value was modified (increased) by an order of magnitude to } \\
\text { account for the elevated temperature. }\end{array}$ \\
\hline calcite & $9.3 \times 10^{-8}$ & $\begin{array}{l}\text { Calculated value for system far from equilibrium and at } \\
70^{\circ} \mathrm{C} \text { based on data from Gutjahr et al. (1996). }\end{array}$ \\
\hline
\end{tabular}

The results of the OS3D/GIMRT simulations are shown in Figures 3-10. In cases where results are identical or can be inferred, the plots have not been included in this report. Plots showing reactant consumption (Figs. $3 \mathrm{a}, \mathrm{b}$ and 7) demonstrate that quartz and magnetite are not significantly affected for the duration of the simulation and that changes in porosity are dependent on lime consumption (Figs. 3 and 7) and calcite and portlandite generation (Figs. 4 and 8). This is true of both ventilated and unventilated cases. The movement of a reaction front through the system as a function of time is clear from the longitudinal profiles of $\mathrm{pH}$, mineral assemblage and aqueous speciation. Plots that compare the chemical profile of the systems at different points in time are illustrated in Figures 6 and 10. The maturation of the transition zone is seen in the change in the slope of the calcite profile in Figures 10b, $\mathrm{c}$ and $\mathrm{d}$ which represent 2 years and 15 years elapsed time respectively.

Similar to the case of the $\mathrm{pH}$ conditioning, the desired Eh conditioning effect (reducing environment) (Figs. $2 \mathrm{~b}$ and d) is acheived only in the case of the closed system. In the open system the Eh remains positive. Although at the end of the OS3D/GIMRT simulations (2-3 years) the amount of magnetite in the system appears unaffected because only a small amount of reactant phase (hematite) (Fig 3a and b) is generated, it is clear from the EQ3/6 simulations that the Eh conditioning effect is transient (Fig $2 b$ ). Given that the effect is only achieved in a closed system and that it would be very difficult to achieve or prove the existence of a pneumatically sealed environment over the time period in question, the extended simulations that would be required to determine the duration of the conditioning effects (Eh or $\mathrm{pH}$ ) were not carried out.

A few engineering considerations become clear from these results. First, fundamental to engineering design is the observation that in the open system $\mathrm{pH}$ is maximized during the transient period, that is, while the system is evolving (see Fig 10b, which has not achieved equilibrium (compare Fig 2c)). In the closed system $\mathrm{pH}$ is maximized during the transient state (see Fig 6a) but remains elevated during the steady state condition in which lime is present (see Fig 2a). Once lime is consumed the $\mathrm{pH}$ decreases. The iron phase only affects oxygen availability in the (pneumatically) closed system (which will be difficult if not impossible to either to engineer or to prove), and even then the effect is transient. Given hydrological scenario associated with the backfill case, in which water will be driven away from the waste packages as a result of elevated temperatures, we suggest that the system will probably have evolved to a hematite + portlandite + quartz assemblage before significant water infiltration occurs.

Other considerations, although not explicitly evaluated in these simulations, bear examination. It is clear from reaction processes that alteration will first occur along grain surfaces, resulting in the formation of a secondary mineral precipitation on and between the original backfill grains. Given the movement of fluids as a reaction front, it is possible that a solidified crust could 
form at the point of water entry into the backfill or at depth. This type of process is well known and is responsible for the formation of lateritic and bauxitic crusts in tropical climates. In an extreme case, the result could profoundly modify assumed hydrological properties of the backfill, including the possible development of fast flow paths to a container surface, and needs careful evaluation. In addition, reaction rate is a function of grain size and water availability, which remained constant for these simulations. Completeness of the reaction may be a function of grain size (passivation may occur in larger grains). Our simulations are conducted assuming that the reaction is complete.

\section{Selection of other potential candidate backfill materials}

A review was conducted of a range of solid phases that may act as potential $\mathrm{pH}$ and redox buffers in backfill material. The approach taken was to consider only metals, oxides, hydroxides, carbonates, sulfides and sulphates. These relatively simple compounds were chosen for consideration because their chemistries are relatively simple, their reaction rates are often well established, and their thermodynamic properties are usually better known than those of more complex compounds. As a result, their potential as backfill material could be better constrained.

Once identified (Table 3), the compounds were evaluated as potential Eh and $\mathrm{pH}$ buffers by first determining the stability field of the phase of interest, using such sources as Helgeson et al. (1978), Brookins (1987), and Johnson et al. (1992). Phases that are stable under high redox conditions and/or low $\mathrm{pH}$ (identified by " $\mathrm{n}$ " in Table 6) would buffer infiltrating water to those respective conditions, and would thus not be suitable as backfill materials, where the criteria for acceptable performance was dictated to be high $\mathrm{pH}$ and/or low redox (i.e., low Eh). Phases that would buffer infiltrating water to high $\mathrm{pH}$ and/or low Eh were identified (indicated by " $\mathbf{Y}$ " in Table 3).

Phases that had the appropriate stability fields were then used in EQ3/6 simulations to determine the $\mathrm{pH}$ and $\mathrm{Eh}$ values that would result if $\mathrm{J}-13$ type water interacted with them at ambient temperatures $\left(31^{\circ} \mathrm{C}\right)$. The criteria was established that the resulting water should have a $\mathrm{pH}>12.0$ and $\mathrm{Eh}<100$ millivolts. The only phase that met both of these criteria was SnS $(\mathrm{pH}=12.8$, $\mathrm{Eh}=-600 \mathrm{mV}$ ). Of the remaining phases $\mathrm{pH}$ ranged between 8.9 and 11.1 , which are not conditions sufficient for backfill performance.

\section{Conclusions}

These simulations demonstrate that a backfill composed of quartz sand, magnetite and lime will not control oxygen fugacity or $\mathrm{pH}$ unless the drifts are completely sealed. Even then the chemical conditioning effects would be minor, and would probably not achieve the engineering goals. A candidate backfill should be further tested over prolonged periods of time, and various temperature gradients. However, the simulations conducted here are sufficient to demonstrate that this backfill option does not sufficiently improve the robustness of the repository concept to warrant further consideration. All of the chemical evolution shown here, including the desired chemical conditioning, take place and are expended in within a matter of decades, which is insignificant with respect to the lifetime of the repository. Given the other potential effects of backfill in general and material specific coupled effects in this case, it is possible that addition of the iron, lime, sand backfill may not add any beneficial effects, but may, by adding complexity to the system, increase uncertainty. 
Table 6: Minerals Considered as Potential $\mathrm{pH}$ and Eh Buffers.

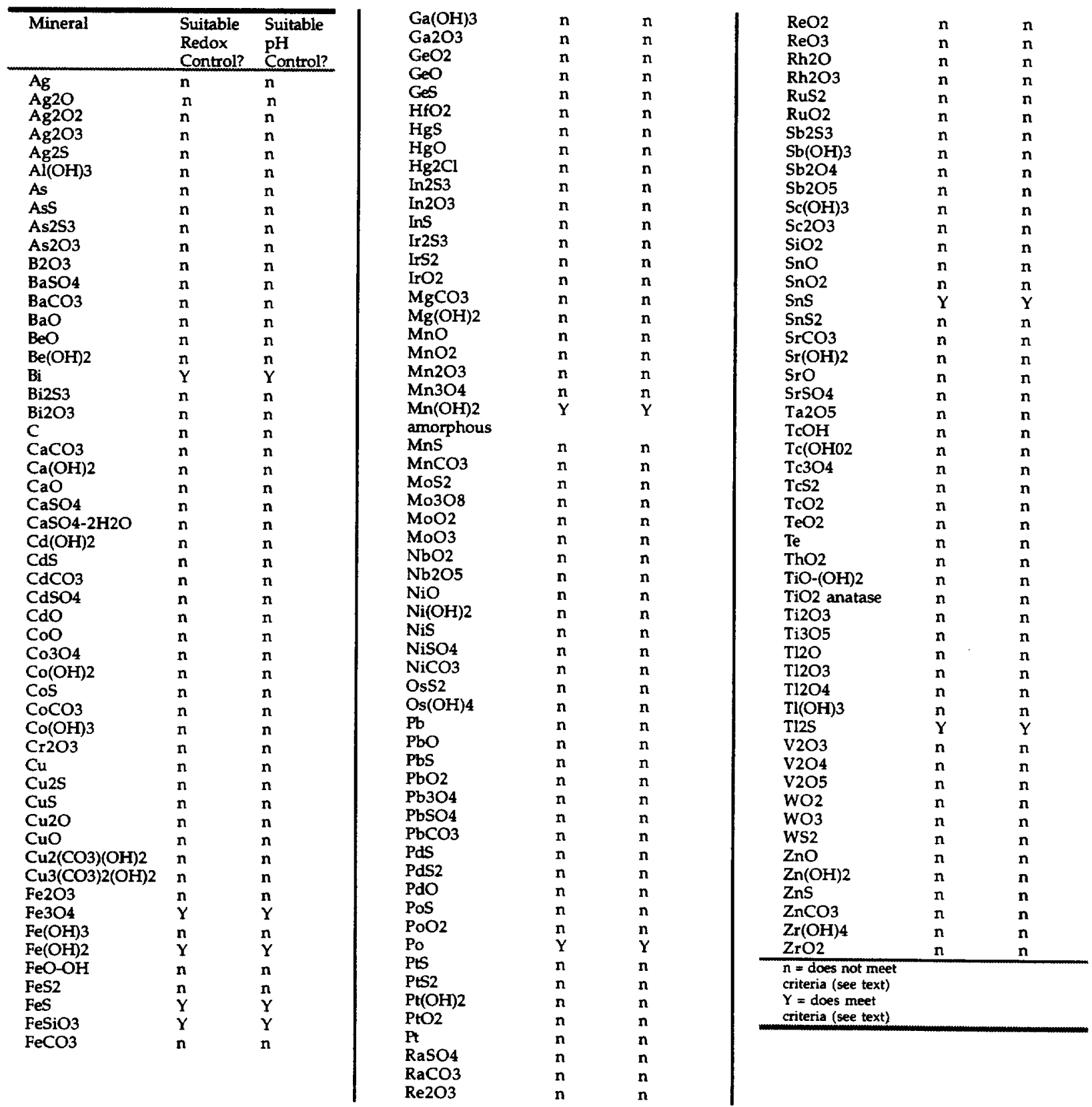




\section{References}

Buscheck, 1996, Chapter 1 Near Field Environment Report. Lawrence Livermore National Laboratory Report.

Brookins, D.G., 1988, Eh-pH Diagrams for Geochemistry. Springer-Verlag, New York. $176 \mathrm{p}$.

Bruno, J., Stumm, W., Wersin, P. and Brandberg, F. (1992) On the influence of carbonate in mineral dissolution. 1. The thermodynamics and kinetics of hematite dissolution in bicarbonate solutions at $\mathrm{T}=25^{\circ} \mathrm{C}$. Geochimica et Cosmochimica Acta. 56: 1139-1147.

Gutjahr , A., Dabringhaus, H., and Ladmann, R. (1996) Studies of the growth and dissolution kinetics of the $\mathrm{CaCO}_{3}$ polymorphs calcite and aragonite.J. Crystal Growth. 158: 296-309.

Helgeson, H.C., Delany, J.M., Nesbitt, H.W., and Bird, D.K., 1978. Summary and critique of the thermodynamic properties of rock-forming minerals. Am. J. Sci., v. 278-A, 229 p.

Horn, J. M., and A. Meike (1995), Microbial Activity at Yucca Mountain, Lawrence Livermore National Laboratory, Livermore, CA, UCRL-ID-122256.

Johnson, J.W., Oelkers, E.H., and Helgeson, H.C., 1992. SUPCRT92: A software package for calculating the standard molal thermodynamic properties of minerals, gases, aqueous species, and reactions from 1 to 5000 bars and 0 to $1000 \mathrm{oC}$. Computers and Geosciences, v. 18, p. 899-947.

Knauss, K. G. and Wolery T. J. (1988) The dissolution kinetics of quartz as a function of $\mathrm{pH}$ and time at $70^{\circ} \mathrm{C}$. Geochimica et Cosmochimica Acta. 52: 43-53.

Sassani, D. (1995) Oral Presentation CRWMS M\&O. File number LV.PA.DCS.7/95.053.

Steefel, C.I., and Lasaga, A.C., 1994, A coupled model for transport of multiple chemical species and kinetic precipitation/dissolution reactions with application to reactive flow in single phase hydrothermal systems: Amer. J. Sci., v. 294, p. 529-592.

Steefel, C.I., and Yabusaki, S.B., 1995, OS3D/GIMRT: Software for modeling multicomponent-multidimensional reactive transport: User's manual and programmer's guide, Version 1.0, $58 \mathrm{p}$.

Van Lier, J. A., de Bruyn and J. Th. G. Overbeek (1960) The solubility of quartz. J. Phys. Chem 64: 1675-1682.

Vinson, D. W. Nutt, W. M. and Bullen, D. B. Survey of the degradation modes of candidate materials for high-level radioactive waste disposal containers. Lawrence Livermore National Laboratory Report. UCRL-CR-120464.

White, A. F., Peterson, M. L. and Hochella, M.F. Jr. (1994) Electro-chemistry and dissolution kinetics of magnetite and ilmenite. Geochimica et Cosmochimica Acta. 58: 1859-1875.

Wolery, T., et al. (1990), Current Status of the EQ3/6 Software Package for Geochemical Modeling, in Chemical Modeling in Aqueous Systems II. Lawrence Livermore National Laboratory Report. NNA.19900716.0363 


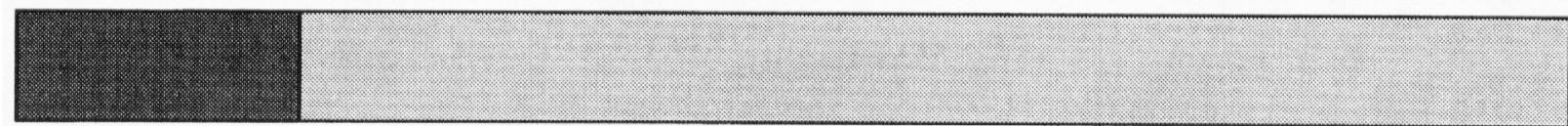

\section{Initial condition}

J-13 water +backfill

$100 \%$ RH v. low ionic strength water +backfill

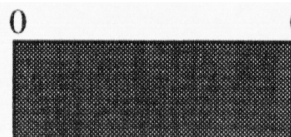

0.2

\section{3}

J-13 water

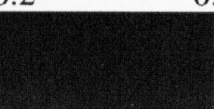

$1.0 \mathrm{~m}$

+backfill (evolving)

incipient reaction zone

$100 \% \mathrm{RH}$ v. low ionic strength water +backfill (evolving)

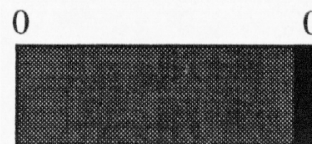

0.2

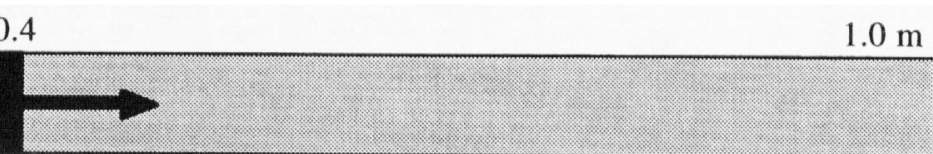

Interim condition

J-13 water

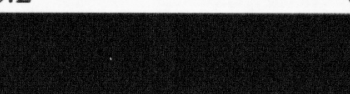

evolving

$100 \%$ RH v. low ionic strength (VLIS) water

+backfill (evolving)

reaction zone

+backfill (steady state)

$(15 \mathrm{yrs})^{*}$

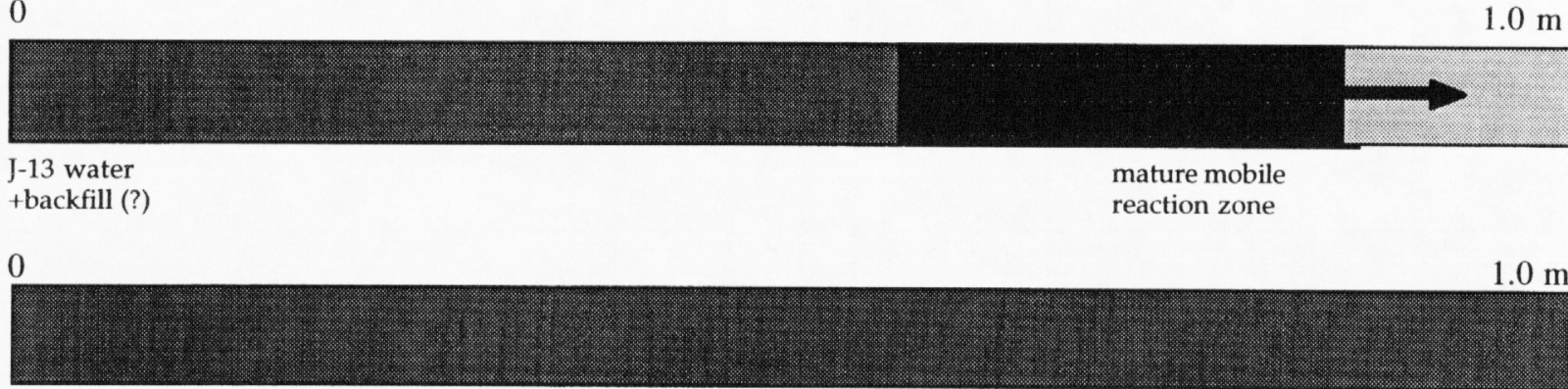

Interim condition

$(? \mathrm{yrs})^{*}$

$100 \%$ RH VLIS water +backfill (steady state)

Steady state $\mathrm{J}-13+\mathrm{qtz}+$ hematite+calcite+minor phases

Figure 1. Illustration of one dimensional reaction progress using OS3D/GMRT. Model uses saturated system, and the original assemblage is not stable in an aqueous environment. Consequently, the system is evolving at all points. The $\mathrm{J}-13$ and pure $\mathrm{H}_{2} \mathrm{O}$ zones evolve toward steady state and the reaction zone matures and moves through the system. In comparison, reaction progress of unsaturated system depends on water availability. 

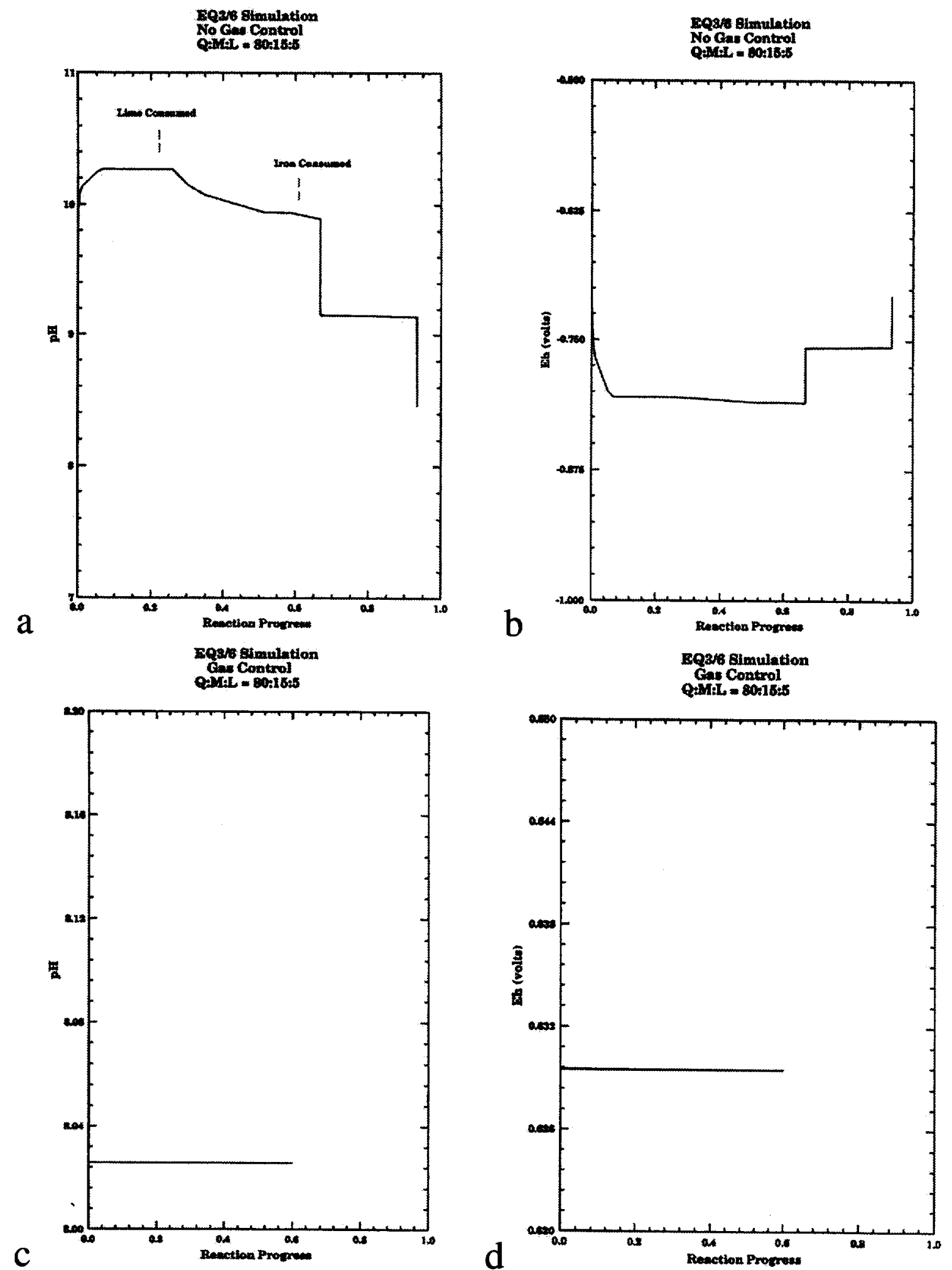

Figure 2. EQ $3 / 6$ simulations of the magnetite, lime, and quartz sand (80:15:5 molar ratio) backfill. a) $\mathrm{pH}$ and b) Eh vs. reaction progress for a closed system (no gas control, i.e. "unfixed" $\mathrm{fO}_{2}$ and $\mathrm{fCO}_{2}$ ). c) $\mathrm{pH}$ and d) Eh vs. reaction progress for an open system (i.e." fixed" $\mathrm{fO}_{2}$ and $\mathrm{fCO}_{2}$ ). 
Backin, No Gas Control

Quartz: Magnetite : Lime is $80: 15: 5$

Inlet Location

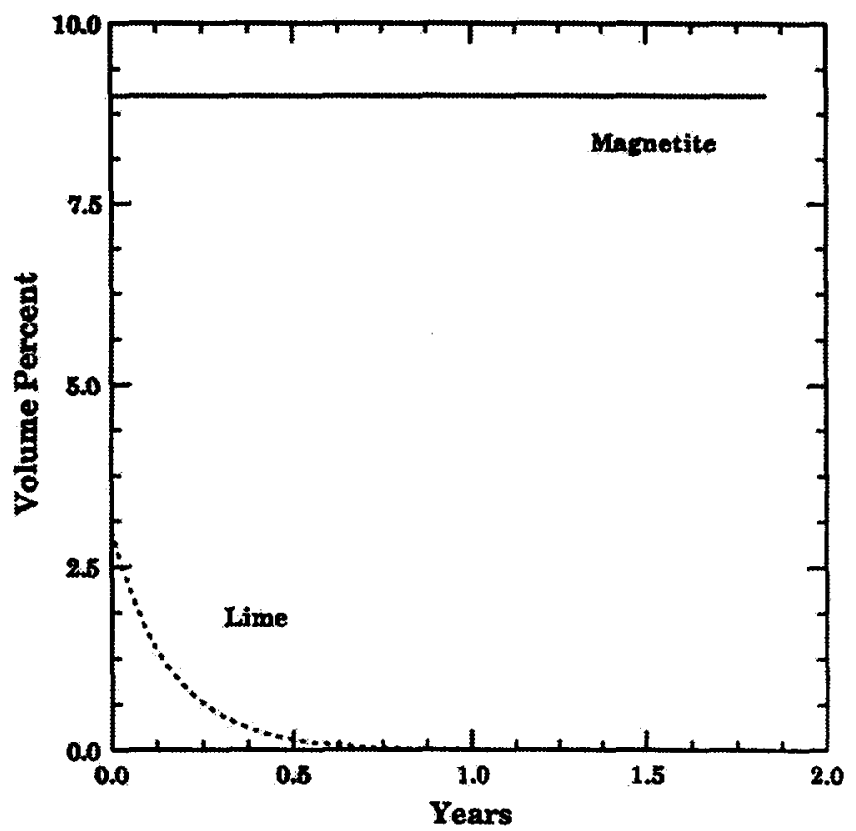

a

Backful, No Gas Control

Quartz: Magnetite : Lime is 80 : $15: 5$

Inlet Location

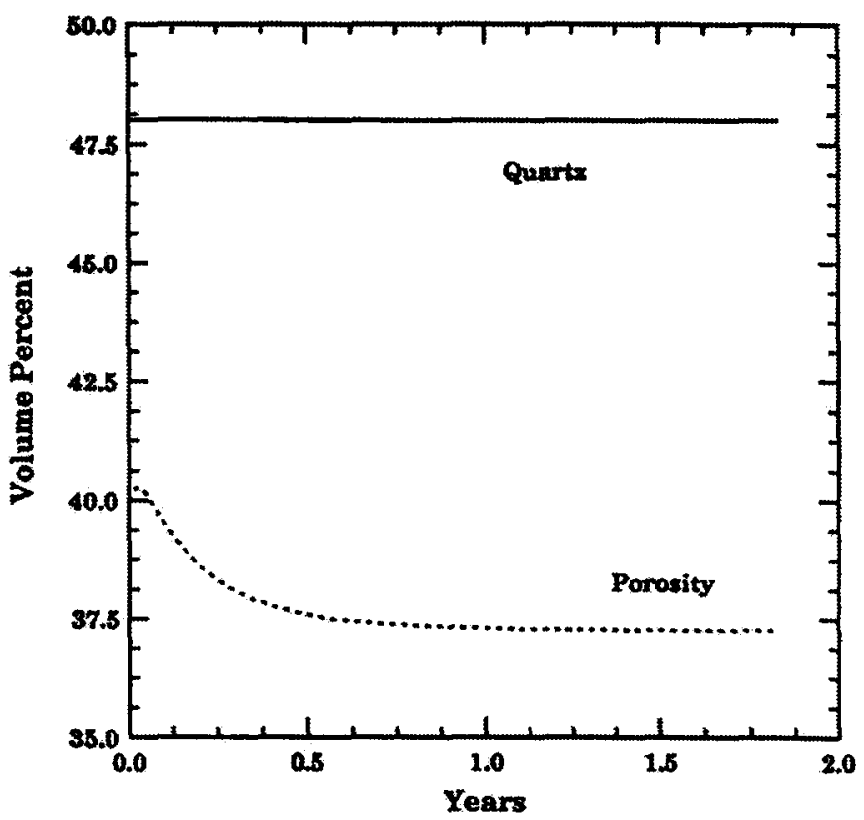

b

Figure 3. OS3D/GIMRT simulations of reactant consumption and porosity at the inlet $(0 \mathrm{~m})$ for the magnetite, lime, and quartz sand (80:15:5 molar ratio) backfill in a closed ("unfixed") system. a) Volume percent of magnetite and lime as a function of time (2 year duration).

b) Volume percent of quartz and porosity as a function of time ( 2 year duration). 

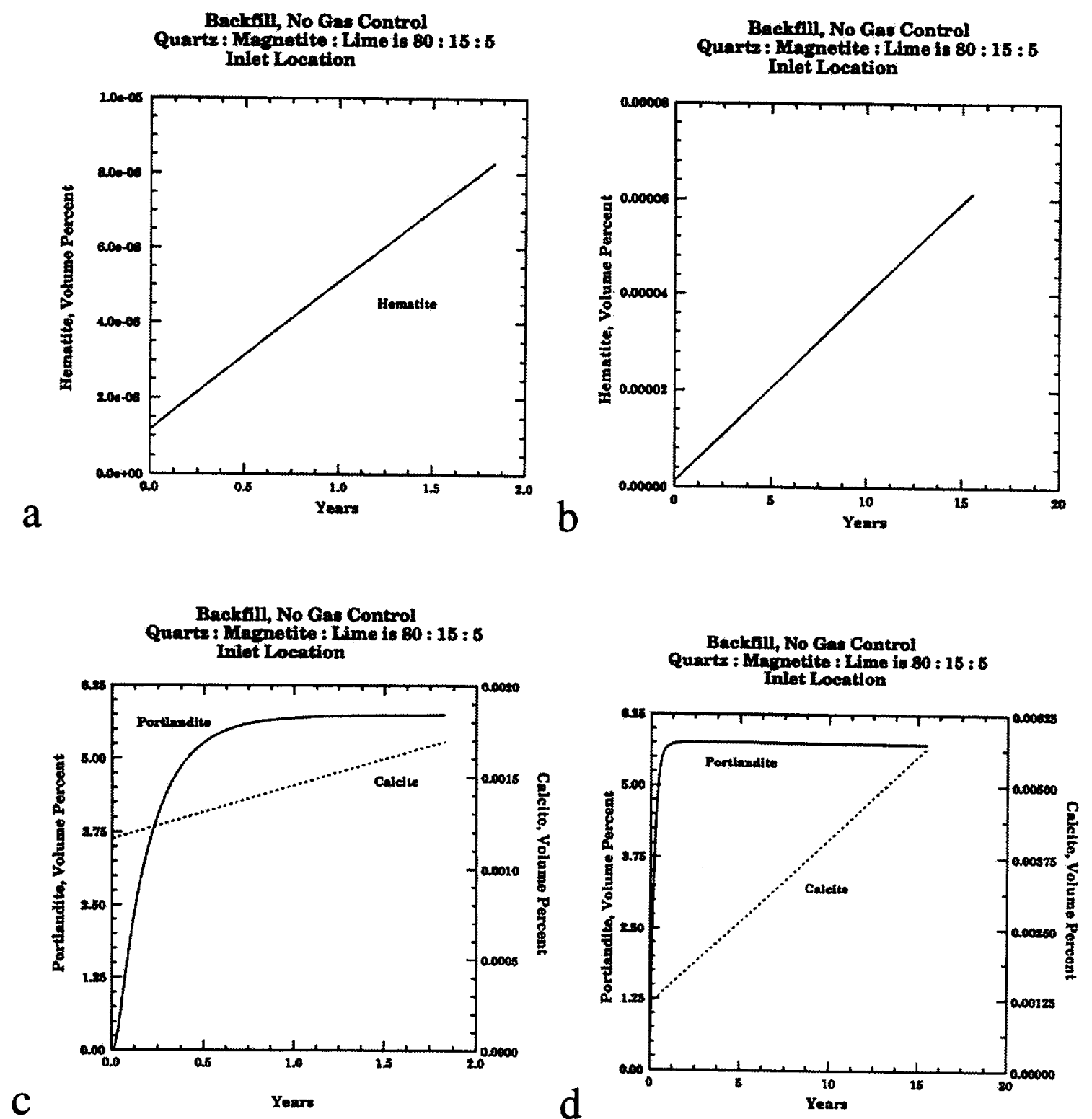

Figure 4. OS3D/GIMRT simulations of product evolution at the inlet $(0 \mathrm{~m})$ for the magnetite, lime, quartz sand backfill system (80:15:5 molar ratio) for the closed ("unfixed") system. Note that calcite volume percent is plotted with respect to the right axis. a) Hematite evolution as a function of time ( $2 \mathrm{yr}$. duration). b) Hematite evolution as a function of time (20 yr. duration). c) Portlandite and calcite evolution as a function of time (2 yr. duration). d) Portlandite and calcite evolution as a function of time (20 yr. duration). 

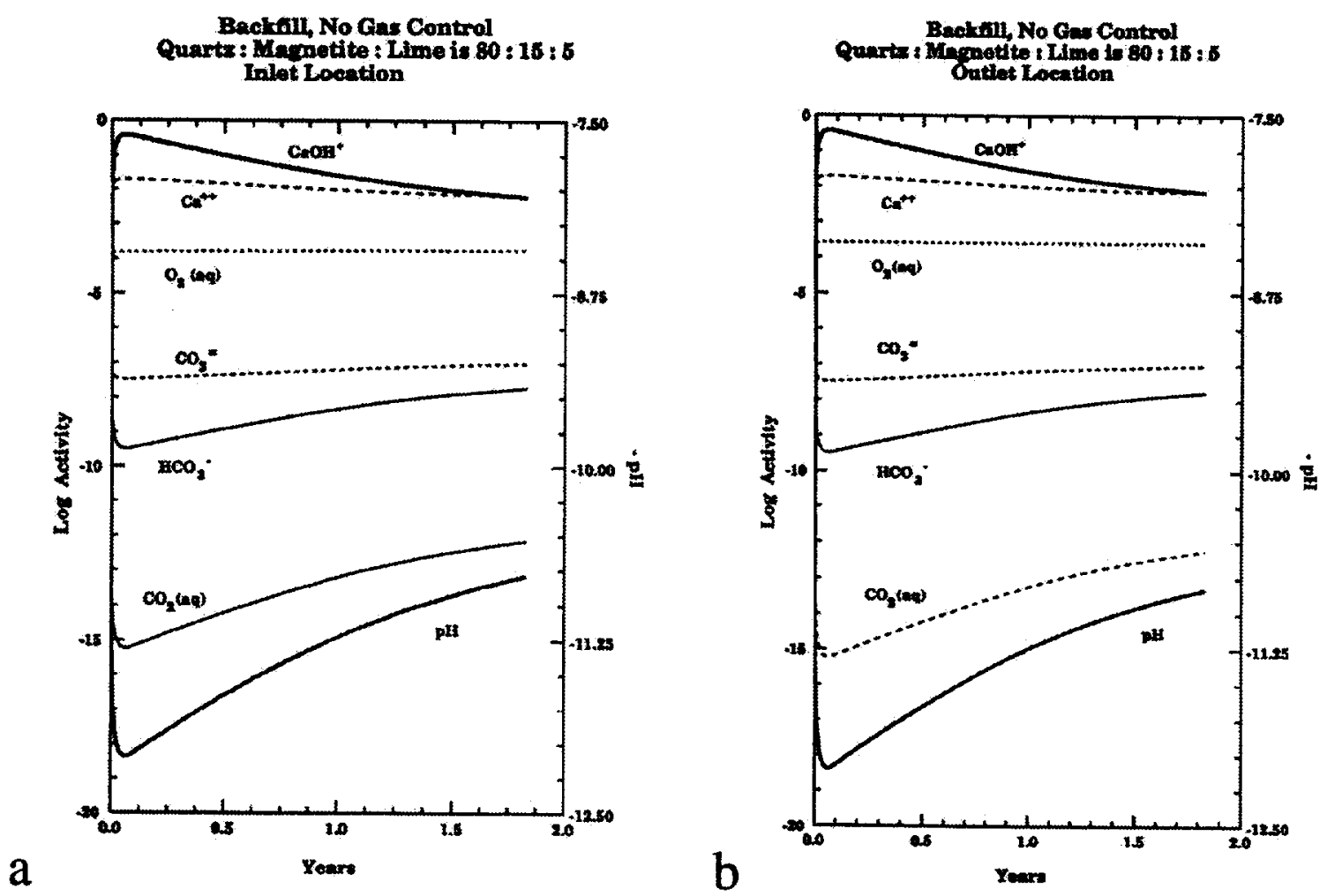

Figure 5. OS3D/GIMRT simulations of chemical speciation in the aqueous phase vs. time for the closed ("unfixed") system. a) Inlet location (2 yrs.). b) Outlet location (2 yrs.).
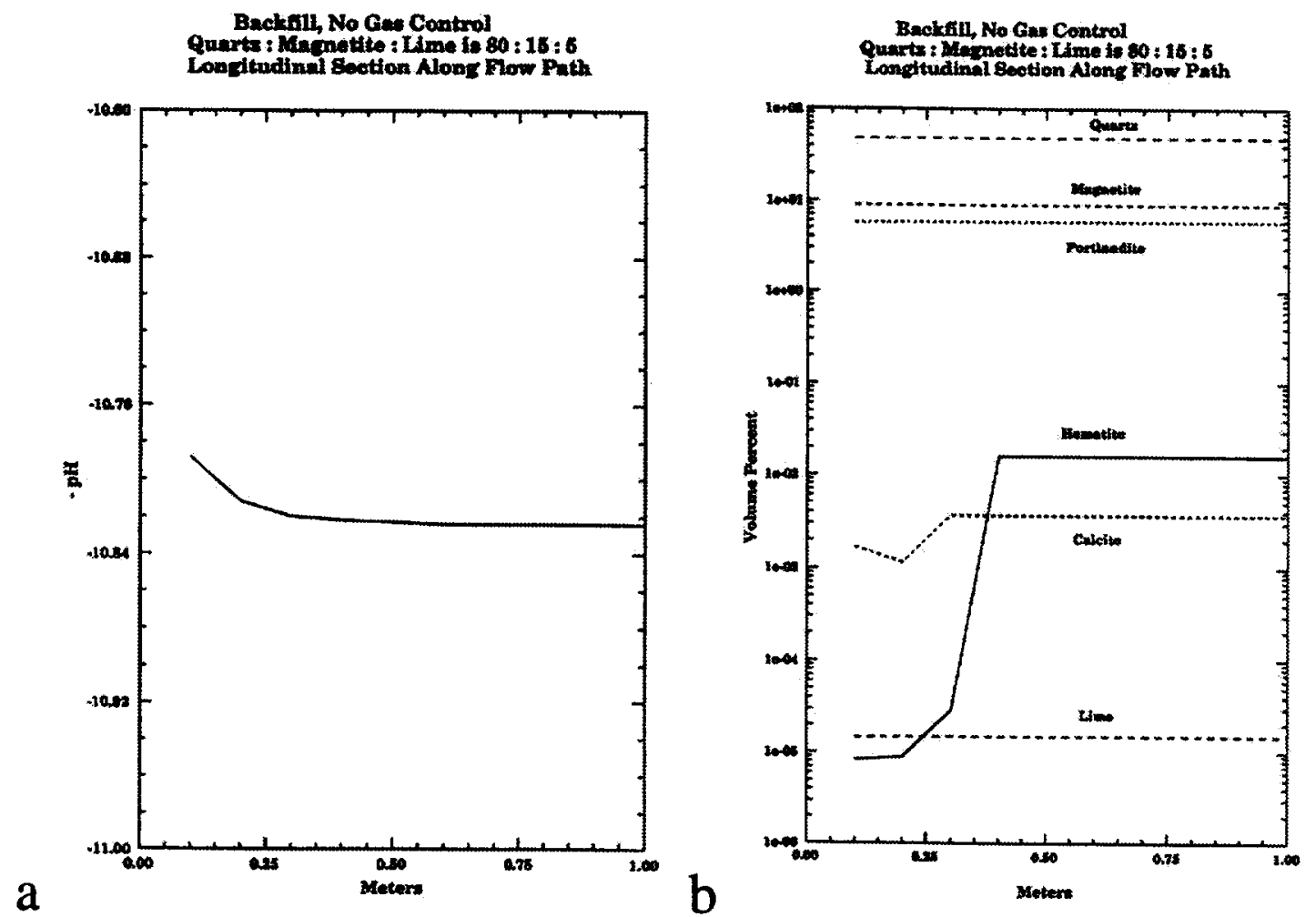

Figure 6. OS3D/GIMRT longitudinal sections for the closed ("unfixed") system. a) pH profile at 2 years. b) Mineral phase profile at 2 years. 
Backnil, Gas At Atmospheric Values

Quartz : Magnetite : Lime is $80: 16: 5$

Inlet Location

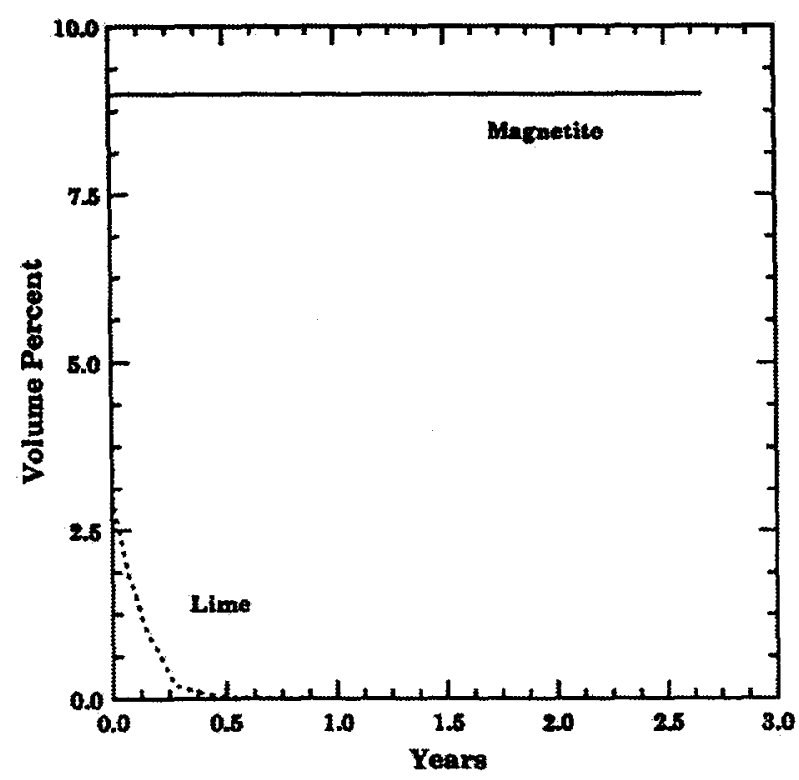

Figure 7. OS3D/GIMRT simulations of reactant consumption and porosity at the inlet $(0 \mathrm{~m})$ for the magnetite, lime, quartz sand backfill system (80:15:5 molar ratio) for the open ("fixed") system. Volume percent of magnetite and lime as a function of time (2 yrs.).

\section{Backfill, Gas At Atmospheric Values}

Quartz : Magnetite : Lime is $80: 15: 6$ Inlet Location

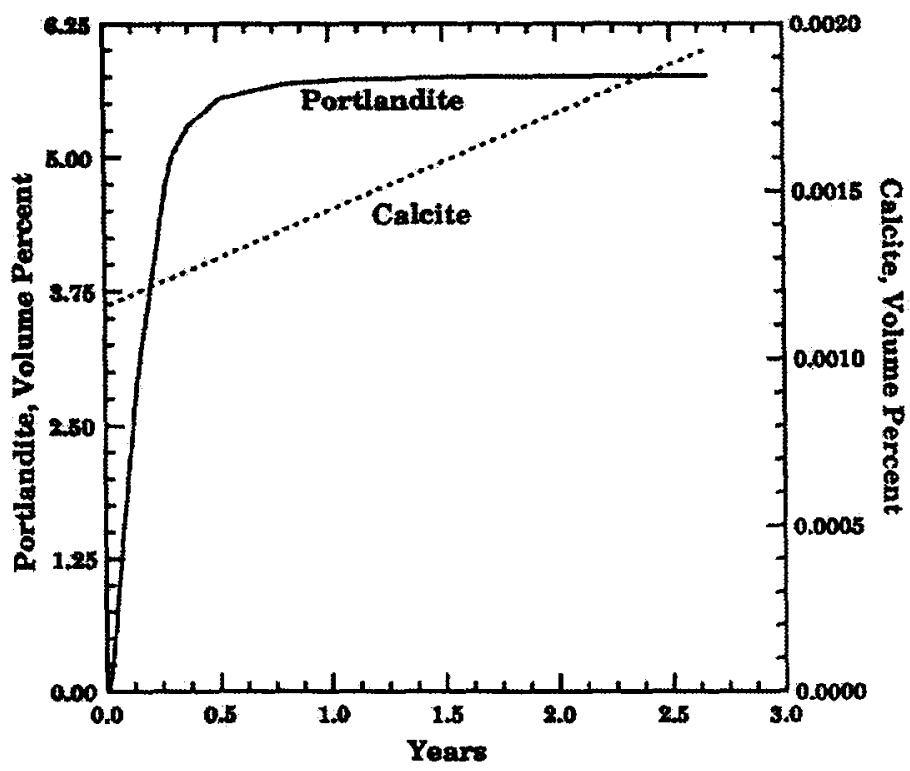

Figure 8. OS3D/GIMRT simulations of product evolution at the inlet $(0 \mathrm{~m})$ for the magnetite, lime, quartz sand backfill system (80:15:5 molar ratio) for the open ("fixed") system.

Portlandite and calcite evolution is illustrated as a function of time ( $2 \mathrm{yrs}$.). 


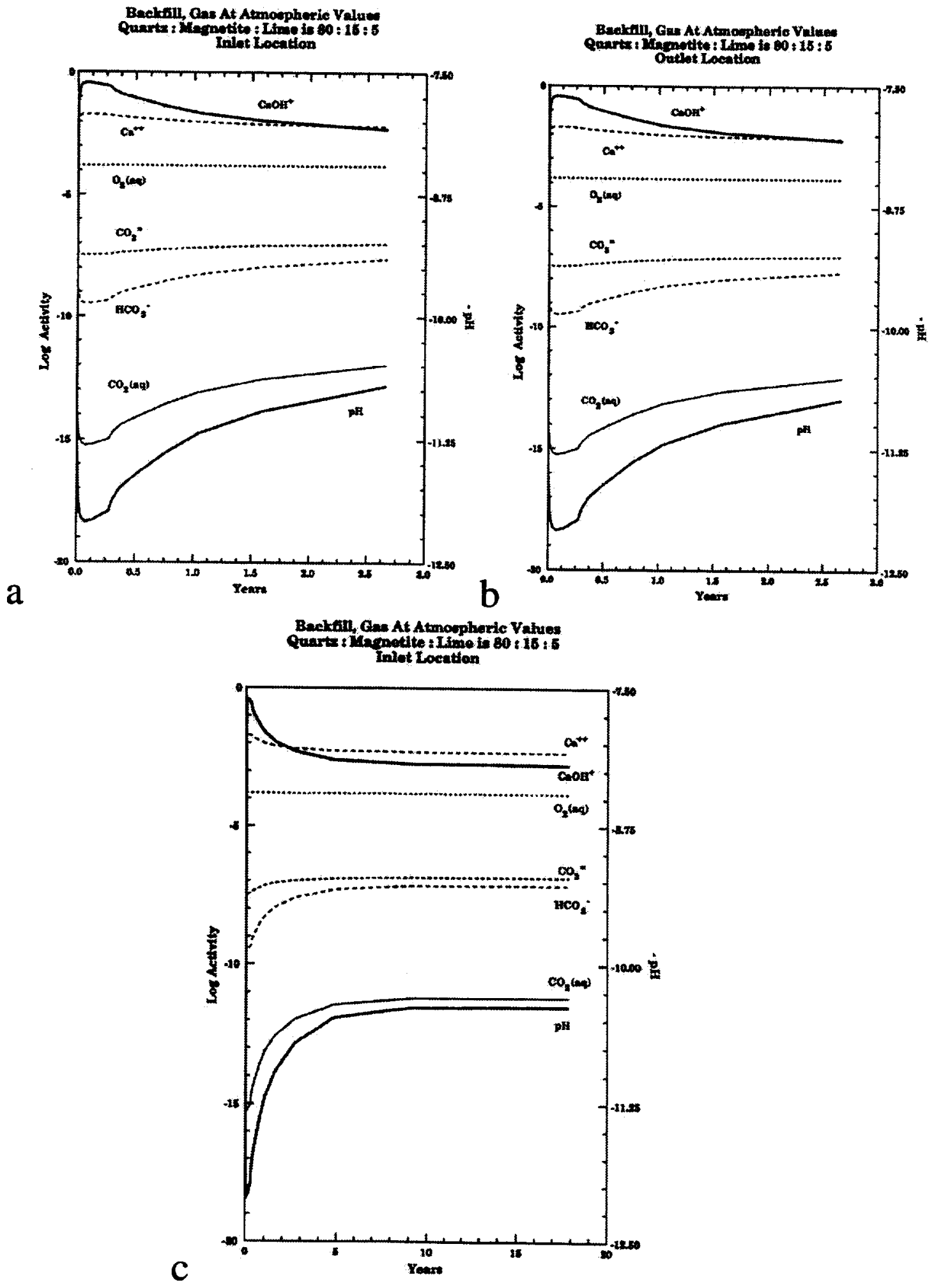

Figure 9. OS3D/GIMRT simulations of chemical speciation in the aqueous phase as a function of time for the open ("fixed") system. a) Inlet location ( 3 yrs.). b) Outlet location $(3 \mathrm{yrs}$.$) . c) Inlet location (20 yrs.).$ 

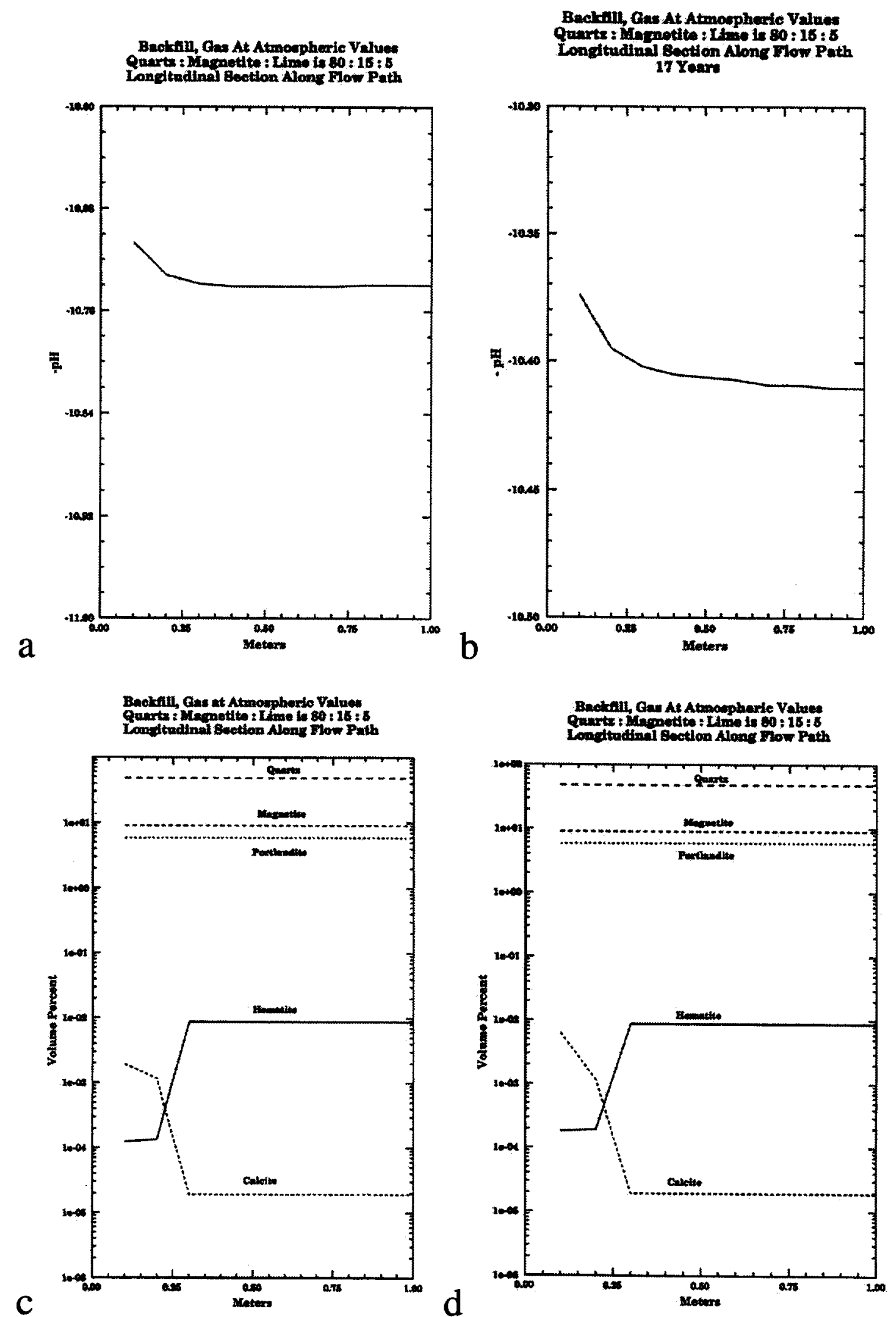

Figure 10. OS3D/GIMRT longitudinal sections for the open ("fixed") system. a) pH profile at 2 years. b) $\mathrm{pH}$ profile at 17 years. c) Mineral phase profile at 2 years. d) Mineral phase profile at 15 years. 
. 


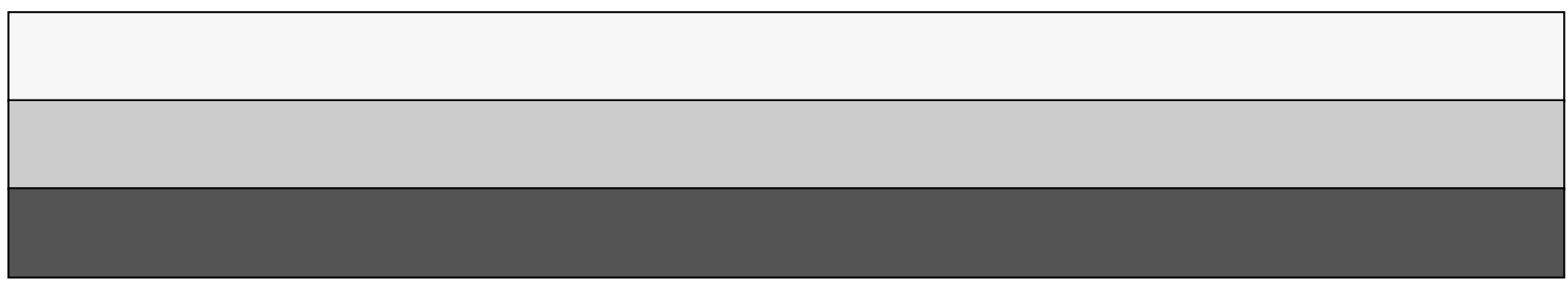

